\title{
Seroprevalence of Toxoplasma gondii in patients receiving cancer treatment
}

\section{Kanser tedavisi alan hastalarda Toxoplasma gondii seroprevalansı}

\author{
Mehtap Alimm ${ }^{1}$, Semra Özçeliik², Necati Özpınar ${ }^{3}$
}

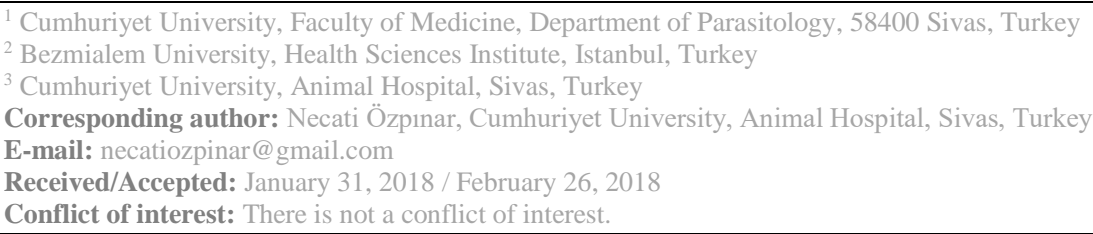

\section{SUMMARY}

Objective: Toxoplasma gondii (T. gondii) is a protozoon infecting many living species in the world and causing clinical pictures that can end with death in humans, especially in patients with blunted immune system. Chemotherapy and radiotherapy administrations in cancer patients cause the reactivation of latent $\mathrm{T}$. gondii by impairing both cellular and humoral immune system. The purpose of this study is to determine the seroprevalence of $T$. gondii in patients who have applied to and received cancer treatment in the Health Services Research and Application Hospital of Cumhuriyet University in Sivas

Method: The study was conducted on the patients aged between 18-80, who applied to the Radiation Oncology Polyclinic in the Health Services Research and Application Hospital of Cumhuriyet University and the sample consisted of 100 cancer patients receiving chemotherapy and 100 healthy people in the control group. Toxoplasma IgG and IgM antibodies were analyzed with the ELISA method in the blood samples taken from this peoples.

Results: In our study, Toxoplasma IgG positivity was determined in $60(60.0 \%)$ of the 100 cancer patients receiving chemotherapy in the Health Services Research and Application Hospital of Cumhuriyet University and 27 (27.0\%) of the control group. The difference between the groups was found to be significant. Cancer patients included in the study consisted of especially lung cancer, breast cancer, stomach cancer, colon cancer and ovarian cancer patients. IgM positivity $(1.0 \%)$ was determined in one individual in both the cancer patients and the control group, and the difference between the groups was found to be insignificant.

Conclusions: Opportunistic infections like toxoplasmosis are more frequent in cancer patients with the blunted immune system compared to individuals with the normal immune systems. These individuals are more prone to infections and the risk of the reactivation of toxoplasmosis experienced before is higher in these patients. Therefore, it will be appropriate for these patients to be periodically evaluated in terms of Toxoplasma.

Keywords: Toxoplasma gondii, anti-Toxoplasma IgG, anti-Toxoplasma IgM, seroprevalance, cancer

\section{ÖZET}

Amaç: Toxoplasma gondii dünya üzerinde pek çok canlı türünü enfekte eden ve insanlarda özellikle immun sistemi baskılanmıș hastalarda ölümle sonuçlanabilecek klinik tablolara yol açan bir protozoondur. Kanser hastalarında uygulanan kemoterapi ve radyoterapi hem hücresel hem de humoral immun sistemi bozarak latent durumda bulunan $T$. gondii' nin reaktivasyonuna yol açmaktadır. Çalışmamızda, Sivas Cumhuriyet Üniversitesi Sağlık Hizmetleri Uygulama ve Araştırma Hastanesine başvuran ve kanser tedavisi gören hastalarda T. gondii seroprevalansının ELISA yöntemi ile belirlenmesi amaçlanmıştır. 
Yöntem: Çalışma, Cumhuriyet Üniversitesi Sağlık Hizmetleri Uygulama ve Araştırma Hastanesi Radyasyon Onkolojisi Polikliniğine başvuran, 18-80 yaş aralığında hastalar üzerinde yapılmış ve örneklem sayısı, 100 kemoterapi alan kanser hastası ve 100 sağlıklı kontrol grubu kişiden oluşturulmuştur. Bu kişilerden alınan kan örneklerinde Toxoplasma IgG ve IgM antikorları ELISA yöntemi ile araştırılmıştır.

Bulgular: Çalışmamızda, Cumhuriyet Üniversitesi Sağlık Hizmetleri Uygulama ve Araştırma Hastanesinde kemoterapi alan 100 kanserli hastanın 60'ında (\%60.0) IgG pozitifliği saptanmış olup, kontrol grubunun 27'sinde (\%27.0) pozitiflik görülmüştür. Aralarındaki farklılık önemli bulunmuştur. Çalışmaya alınan kanser hastaları başlıca; akciğer, meme, mide, kolon, over kanserlerinden oluşmaktadır. Kanserli hastalarla kontrol grubunun her ikisinde de bir kişide (\%1.0) IgM pozitifliği saptanmış olup gruplar arası farklılık önemsiz bulunmuştur.

Sonuç: Bağışıklık sistemi baskılanmış kanser hastalarında, bağışıklık sistemi normal olan bireylerde daha nadir görülen toksoplazmoz gibi fırsatçı infeksiyonlara daha sık rastlanmaktadır. Bu kişiler hem enfeksiyonlara daha yatkındır hem de daha önce geçirilmiş olan toksoplazmozun reaktivasyon riski bu hastalarda daha yüksektir. Bu nedenle; bu hastaların belirli periyotlarla Toxoplasma açısından değerlendirilmeleri uygun olacaktır.

Anahtar sözcükler: Toxoplasma gondii, anti-Toxoplasma IgG, anti-Toxoplasma IgM, seroprevalans, kanser

\section{INTRODUCTION}

Toxoplasma gondii (T. gondii) is an obligate intracellular parasite and is in the Apicomplexa, the subphylum of protozoa. It was first observed in "Ctenodactylus gondii", an African rodent, and described by Charles Nicolle and L. Manceau in $1908^{1}$.

T. gondii is one of the frequently encountered protozoon parasites in the world and has a very broad host spectrum. Felidae hosting the factor can transmit this factor in a vertical way to the off spring, therefore, the spread potential of $T$. gondii is inherited from generation to generation. The free spread of oocysts in the natural environment by Felidae poses a risk for all living species in terms of toxoplasmosis. It is reported in the studies conducted that $T$. gondii oocysts present in the feces of approximately $1 \%$ of the Felidae in the world ${ }^{2}$. In the studies conducted in different countries on domestic cats, which are the important source of the disease, $10-80 \%$ positivity was determined especially in young animals and $0.16 \%$ of the cats in Central Europe were determined to discharge oocysts with the feces ${ }^{3}$. Seropositivity varying between $37.5-55.5 \%$ was determined in cats in a study conducted in Turkey ${ }^{4}$. No toxoplasmosis was reported to be present on small islands in the Pacific Ocean where cats had never been presented ${ }^{5}$. Seropositivity of toxoplasmosis varies between $5-90 \%$ around the world. The prevalence of toxoplasmosis was reported to change between $12-65 \%$ in the studies conducted in Turkey ${ }^{6}$.

T. gondii is one of the possible risk factors in the etiology of the diseases such as Schizophrenia, Parkinson and Alzheimer, with pathologies it causes by settling in the brain tissue and nervous system, in the suicide attempt, brain cancer development and diabetes, $T$. gondii is being investigated in such diseases ${ }^{7}$.

T. gondii is an obligate intracellular parasite and it causes the development of infection in mammals and some bird species. T. gondii is transmitted to humans by the intake of the tissue cysts containing bradyzoites or the foods contaminated with oocysts in the feces of cats. While transmission can occur with the ingestion of the infected raw or rarecooked meat it can also occur by the means of hands that have got into contact with the infected meat. Mothers infected with $T$. gondii during the pregnancy can transmit the infection to the baby. The time of contracting the infection affects the level of the infection in the baby. The transmission of the disease can occur in many ways such as, in a placental way, blood transfusion, and tissue transplantation. Considering the transmission ways of $T$. gondii to humans, hands should be washed thoroughly with water and soap after the contact with the cat, gardening and after working in the soil for the protection from $T$. gondii. The seropositivity of toxoplasmosis varies by region in Turkey. Toxoplasmosis generally presents an asymptomatic course in humans with a competent immune system ${ }^{8}$.

T. gondii is a protozoon infecting many living species in the world and causing clinical pictures that can end with death in humans, especially in patients with suppressed immune system. Chemotherapy and radiotherapy administered to cancer patients, malignant diseases, immune suppressive therapy, corticosteroids and splenectomy can cause the reactivation of latent $T$. gondii by impairing both cellular and humoral immune system. Immune system deficiency observed as a result of the primary disease, chemotherapy and radiotherapy administrations in patients with cancer causes a decrease in $\mathrm{T}$ lymphocyte count and function disorder and a 
decrease in the response to hapten in B lymphocytes. In conclusion, the reactivation of $T$. gondii infection in these patients usually courses with the symptoms that can develop mostly in the central nervous system ${ }^{9}$.

The purpose of this study was to determine the seroprevalence $T$. gondii in patients who have visited and received cancer treatment in the Health Services Research and Application Hospital of Cumhuriyet University in Sivas.

\section{MATERIAL AND METHODS}

The study was conducted on patients aged between 18-80, who visited the Radiation Oncology Polyclinic in the Health Services Research and Application Hospital of Cumhuriyet University and the sample consisted of 100 cancer patients receiving chemotherapy and 100 healthy people in the control group.

2-3 ml blood samples were collected from patients aged 18-80. The collected blood samples were separated from the serum by centrifugation at 1500 $\mathrm{rpm}$ for 10 minutes (min). The serums were preserved in a deep freezer at the temperature of $20{ }^{\circ} \mathrm{C}$ until the day of the study. Toxoplasma $\operatorname{IgG}$ and $\operatorname{IgM}$ antibodies in the test serums were analyzed with the ELISA method by using the commercial kits of Dia Pro brand (Italy).

\section{Statistical analysis}

Since the parametric test assumptions were not fulfilled in the evaluation of the data by entering the data obtained in this study into SPSS (Ver:22.0) program, the Kruskal-Wallis test, Mann-Whitney $\mathrm{U}$ test and chi-square test were used and the level of error was accepted as 0.05 .

\section{RESULTS}

Cancer patients included in the study were suffering from especially lung cancer, breast cancer, stomach cancer, colon cancer and ovarian cancer and the positivity of Toxoplasma $\operatorname{IgG}$ of these patients obtained with the ELISA method are provided in Table 1. Accordingly, IgG positivity was in $60(60.0 \%)$ of the 100 cancer patients, and when compared to the control group, the difference was found to be significant $(p<0.05)$. IgM positivity was in one individual in both cancer patients and the control group, and the difference between the groups was found to be insignificant (p>0.05). Furthermore, both Toxoplasma IgG and IgM positivities were in one of the patients $(\mathrm{p}>0.05)$.

Table 1. Distribution of Toxoplasma IgG results of the Cancer and Control groups

\begin{tabular}{|c|c|c|c|c|c|c|}
\hline \multirow{3}{*}{ GROUPS } & \multicolumn{4}{|c|}{ ELISA IgG } & \multicolumn{2}{|c|}{ Total } \\
\hline & \multicolumn{2}{|l|}{ Positive } & \multicolumn{2}{|l|}{ Negative } & \multirow[b]{2}{*}{ Number } & \multirow[b]{2}{*}{$\%$} \\
\hline & Number & $\%$ & Number & $\%$ & & \\
\hline Cancer patients & 60 & 60 & 40 & 40 & 100 & 100 \\
\hline Control & 27 & 27 & 73 & 73 & 100 & 100 \\
\hline
\end{tabular}

\section{DISCUSSION}

Khalil et al. (1991) determined seropositivity in 40 (36\%) patients with titrations changing at the ratio of $1 / 16-1 / 256$ with the IFAT method among 111 cancer patients ${ }^{10}$.

Gungor et al. (1993) investigated the Toxoplasma antibodies in the serums of 30 leukemia patients taking immune suppressive drugs with the ELISA and Sabin-Feldman methods. Toxoplasma IgM positivity was determined at the rate of $6.7 \%$ in the control group, and this rate was found to be $26.7 \%$ in the patient group with the ELISA method. Furthermore, while Toxoplasma IgG positivity was determined to be $40 \%$ in the control group, this rate was $63.3 \%$ in the patient group. $46.7 \%$ Toxoplasma $\mathrm{IgG}$ positivity was determined in the control group and $66.7 \%$ positivity was determined in the patient group with the Sabin-Feldman method. Gungor et al. (1993) stated that the patients being low in number could be the reason for the high rates; however, this opportunistic pathogen could lead to death with the reactivation of the latent infection as a result of the suppressed immune system in patients with malignant diseases receiving radiotherapy and chemotherapy depending on the disease or for the treatment of the disease ${ }^{11}$.

Huang et al. (1999) investigated the toxoplasmosis seroprevalence in 59 patients with gynecologic 
benign tumor and 50 females with cervical cancer with the ELISA method. Seropositivity was in 22 $(44 \%)$ of the 50 females with cervical cancer and in $15(25.4 \%)$ of the 59 females with gynecologic benign tumor. $20 \%$ Toxoplasma IgG positivity was in the patients with cervical cancer and $11.9 \%$ Toxoplasma IgG positivity was determined in the patients with gynecologic benign tumor. Toxoplasma IgM positivity was $20 \%$ and $13.6 \%$, respectively. Especially Toxoplasma IgM positivity was determined to be high in the cervical cancer group ${ }^{12}$.

Wang et al. (1999) reported that Toxoplasma IgG antibodies were respectively $19 \%, 33.3 \%, 16.5 \%$, $45.4 \%$ and $20 \%$ positive in a total of 100 patients in the groups of cancer patients receiving chemotherapy, patients with chronic liver disease, patients taking immunosuppressive drugs, lymphoma and leukemia patients in a study they conducted in China ${ }^{13}$.

Hokelek et al. (2001) investigated the seroprevalence of $T$. gondii in patients receiving antineoplastic chemotherapy. Fifty-five patients receiving antineoplastic chemotherapy and 46 healthy individuals were included in the study, and T. gondii specific $\operatorname{IgG}$ antibody was found to be above the cut-off value in $36(65.5 \%)$ of the 55 patients and in $19(41.3 \%)$ of the control group. The difference between the two groups was found to be significant. Toxoplasma IgM antibody was determined to be negative in both groups. It was stated in the study that this opportunistic pathogen could lead to death with the reactivation of the latent infection as a result of the suppressed immune system in patients receiving antineoplastic chemotherapy ${ }^{14}$.

T. gondii seropositivity was determined in 41 (74.54\%) of the 55 cancer patients in the study conducted in Van Region in Turkey. Agglutination was determined at $1 / 32$ titration in 21 of the seropositive patients, at $1 / 64$ titration in 10 , at $1 / 128$ titration in 6 and at $1 / 256$ titration in 4 of the seropositive patients. $7.27 \%$ seropositivity at high titrations was evaluated as significant. 14 of the 55 cancer cases were determined to be seronegative ${ }^{15}$.

Yazar et al. (2004) investigated the existence of Toxoplasma antibodies in 108 patients with neoplasia and 108 healthy individuals in the control group in the study they conducted to determine the prevalence of Toxoplasma antibodies in patients with neoplasia using the micro-ELISA method. Toxoplasma $\mathrm{IgG}$ antibody were determined to be positive in $68(63.0 \%)$ of the patients and 21 (19.4\%) of the control group, and the difference between the results obtained was found to be statistically significant. Toxoplasma IgM antibody was determined as positive in $7(6.5 \%)$ of the patients and $1(0.09 \%)$ of the control group. High Toxoplasma antibody positivity was determined in patients with neoplasia; therefore, the parasitological surveys of this patient group should be periodically conducted ${ }^{16}$.

Shin et al. (2009) controlled the Toxoplasma IgG antibody titrations in 1265 patients and the medical records of seropositive patients to understand the epidemiological status and the relationship between toxoplasmosis and other diseases in Daejeon, Korea. Seropositivity was $6.6 \%$ in the latex agglutination test and $6.7 \%$ with the ELISA. A significant difference was determined between the genders and age groups, and positivity was at the peak value especially at the ages between 40 and 49. T. gondii positivity rates were determined to be high in the patients of psychiatry, ophthalmology, emergency medicine and thoracic surgery according to clinical departments, and the incidental major diseases in seropositive cases were determined by frequency as malignant tumors, diabetes mellitus, arthritis, chronic hepatitis B, chronic kidney diseases, schizophrenia and acute lymphadenitis. Antibody titrations were found to be high especially in chronic hepatitis B and cancer patients. According to these results, seropositivity of $T$. gondii was reported to be related to neoplasms, diabetes and other chronic infections ${ }^{17}$.

In a demographic study conducted in France, the incidence of the brain cancer in adults was determined to be higher in the countries where $T$. gondii parasite is frequent. This protozoon was considered to increase the potential risk of tumorigenesis before, and the seroprevalence of $T$. gondii and death rates from the brain cancer were determined to have a positive correlation in adult groups aged 55 and older, and this effect was stated to be strong especially in males ${ }^{18}$.

Deveci et al. (2013) examined the posterior uveitis picture developing in a patient monitored with the ankylosing spondylitis diagnosis and receiving immunosuppressive treatment. Toxoplasma antibodies were investigated and Toxoplasma IgG was positive in the patient. Ankylosing spondylitis (AS) is a significantly chronic, progressive, inflammatory rheumatismal disease characterized by the axial and peripheric joint involvement. The eye involvement was reported to be in the form of anterior uveitis in these patients and to be present in $25-40 \%$ of the patients. Posterior uveitis picture, not anterior uveitis, was followed in patients with AS. However, it was emphasized that this posterior 
uveitis was not a finding of AS disease but $T$. gondii uveitis developed as a result of the immunosuppressive drugs used. Toxoplasmosis was stated to cause infectious necrotizing retinitis and constitute approximately $30-50 \%$ of posterior uveitis. Pregnancy, decrease in the immune resistance, physical and emotional stress were considered to be the triggers of the reactivation of the disease, and the reason for the activation of toxoplasmic retinitis in patients was considered to be steroid and other immunosuppressive drugs used for AS disease ${ }^{19}$.

As a result of the literature review of more than 9256 studies conducted between 1997-2013 in Iran for the information purposes, 22 study records were determined to be suitable for the systematic examination and meta-analysis study. A total of 2805 individuals were included in the analysis and 1326 of these individuals were found to be Toxoplasma IgG seropositive. The results of the systematic investigation and meta-analysis of the toxoplasmosis seroprevalence in patients with the suppressed immune system were determined as $55.1 \%, 50.05 \%, 45.06 \%$, respectively, in transplantation patients, AIDS patients, and cancer patients. Toxoplasma IgM seroprevalence was determined as $4.85 \%$ on average ${ }^{20}$.

Toxoplasma antibodies were investigated with the ELISA in 900 cancer patients and 900 individuals in the control group in the study conducted in China. Toxoplasma seroprevalence was determined to be Toxoplasma $\operatorname{IgG} 35.56 \%$ in cancer patients and $17.44 \%$ in the control group. According to the results obtained, positivity in the patient group was found to be significant and high. The highest $T$. gondii seroprevalence was determined in patients with cervical cancer (50\%), followed by the patients with the brain cancer $(42.31 \%)$ and patients with endometrial cancer (41.67\%). In conclusion, it was stated that $T$. gondii infection was a serious problem in cancer patients and the follow-up of this infection was mandatory in these patients ${ }^{21}$.

In a case presented by $\mathrm{Lu}$ et al. (2015) 1 female patient aged 64 applied to the hospital with the history of a week-long chest pain and coughing for 6 months. Palpable lymphadenopathy was found above the right clavicle in the physical examination. Squamous cell carcinoma diagnosis of the right lung was confirmed by the chest radiography, bronchoscopy and computed tomography. Acute T. gondii infection was determined synchronously in this patient. Toxoplasmosis was stated to be a life-threatening opportunistic infection in patients with lung cancer 22.

In our study, Toxoplasma IgG positivity was determined in $60(60.0 \%)$ of the 100 cancer patients receiving chemotherapy in the Health Services Research and Application Hospital of Cumhuriyet University and $27(27.0 \%)$ of the control group. The difference between the groups was found to be significant. Cancer patients included in the study consisted of especially lung cancer, breast cancer, stomach cancer, colon cancer and ovarian cancer patients. Toxoplasma IgM positivity $(1.0 \%)$ was in one individual in both the cancer patients and the control group, and the difference between the groups was found to be insignificant.

In conclusion, Opportunistic infections like toxoplasmosis are more frequent in cancer patients with the suppressed immune system compared to individuals with the normal immune systems. These individuals are more prone to infections and the risk of the reactivation of toxoplasmosis experienced before is higher in these patients. Therefore, it will be appropriate for these patients to be periodically evaluated in terms of Toxoplasma.

\section{ACKNOWLEDGEMENTS}

This study was supported by CUBAP with the postgraduate thesis project numbered T-635.

\section{ETHICAL APPROVAL}

This study was approved by the decision of the Clinical Trials Ethics Committeeof Cumhuriyet University dated 10.03.2015 and numbered 201503/01.

\section{REFERENCES}

1. Sayg1 G. Parasitic diseases and parasites, Toxoplasmosis 2009; 144-53.

2. Beaman $\mathrm{MH}$, Mc Cabe RE, Wong $\mathrm{S}$, et al.Toxoplasma gondii mandell douglass and bennett's principles and practice of infectious diseases. 4. Edit, Churcill, Livingstone, New York. 1995; 2455-75.

3. Tenter AM, Heckeroth AR, Weiss LM. Toxoplasma gondii: from animals to humans. Int J Parasitol 2000;30:1217-1258.

4. Güler S. Investigation of Anti-Toxoplasma gondiiantibodies in the sheep slaughtered in 
Niğde's laughterhouse using the ELISA test: Science institute, Niğde University. 2011.

5. Sahin I, Onbasi K, Sahin H, et al. Frequency of anti-Toxoplasma antibodies in patients with chronic renal failure undergoing hemodialysis in Van region. Official J Turkish Society of Nephrology 2002; 2: 22-6.

6. Boluk S, Ozyurt BC, Girginkardesler N, et al. Evaluation of serological results of patients with suspected toxoplasmosis admitted to the medical parasitology laboratory of celal bayar university hospital between 2006-2010. Turkish j Parasitol 2012; 36: 137-141.

7. Cevizci S, Bakar C. Toxoplasma gondii with public health's perspective. Turkish J Public Health 2013; 11: 45.

8. Polat M, Kilic E, Yazar S, et al. Assessment of advanced positive oxidation product levels in Toxoplasma gondii positive individuals. Erciyes University, J Health Sci 2012; 21: 200-4.

9. Gulesci E, Oktun M. Investigation of antitoxoplasma antibodies in patients with hematological malignancy Turkish J Parasitol 2005; 29: 85-8.

10. Khalil H, Makled M, Azab M, et al. Opportunistic parasitic infections in immunocompromised hosts. J Egyptian Soc Parasitol 1991; 21: 657-68.

11. Gungor C, Ataoglu H, Altintas K. Investigation of the Toxoplasma IgM, IgG and Sabin-Feldman antibodies in acute leukemia patients taking immunosuppressive drugs. Turkish J Parasitol 1993; 17: 21-6.

12. Huang H, Yan F, Li C, et al. Detection of Toxoplasma infection in women with gynaecologic neoplasms using ELISA. Zhongguo ji sheng chong xue yu ji sheng chong bing za zhi= Chinese J Parasitol \& Parasitic Diseases 1999; 18: 165-66.

13. Wang B, Pan X, Yin Y, et al. Investigation of anti-Toxoplasma gondii antibodies in immunodeficient patients. Zhongguo ji sheng chong xue yu ji sheng chong bing za zhi= Chinese J Parasitol \& Parasitic Diseases 1999; 18:224-226.

14. Hokelek M, Uyar Y, Gunaydin M, et al. Investigation of Toxoplasma antibodies in cancer patients receiving chemotherapy. Turkish J Parasitol 2001; 25: 217-9.

15. Ciftci I.H, Bozkurt H, Guducuoglu H, et al. Toxoplasmosis seroprevalence in cancer patients in Van region. Van Med J 2003; 10 15.

16. Yazar S, Yaman O, Eser B, et al. Investigation of anti-Toxoplasma gondii antibodies in patients with neoplasia. J Med Microbiol 2004; 53: 1183-6.

17. Shin DW, Cha DY, Hua QJ, et al. Seroprevalence of Toxoplasma gondii infection and characteristics of seropositive patients in general hospitals in Daejeon, Korea. Korean J Parasitol 2009; 47: 125-30.

18. Vittecoq M, Elguero E, Lafferty KD, et al. Brain cancer mortality rates increase with Toxoplasma gondii seroprevalence in France. Infection Genetics and Evolution 2012; 12 : 496-8.

19. Deveci H, Kobak S. Toxoplasma uveitis in the case with ankylosing spondylitis. Turkish $\mathbf{J}$ Parasitol 2013; 37: 216-8.

20. Ahmadpour E, Daryani A, Sharif M, et al. Toxoplasmosis in immunocompromised patients in Iran: a systematic review and metaanalysis. J Infection in Developing Countries 2014; 8: 1503-10.

21. Cong W, Liu G.H, Meng Q.F, et al. Toxoplasma gondii infection in cancer patients: prevalence, risk factors, genotypes and association with clinical diagnosis. Cancer letters 2015; 359: 307-13.

22. Lu N, Liu C, Wang J, et al. Toxoplasmosis complicating lung cancer: a case report. Int Med Case Reports J 2015; 8: 37-42. 